\title{
ПОЛУЧЕНИЕ 3,5-ДИАРИЛЗАМЕЩЕННЫХ 5-ГИДРОКСИ- 1,5-ДИГИДРО-2Н-ПИРРОЛ-2-ОНОВ ПУТЁМ ЦИКЛИЗАЦИИ 3-ЦИАНОКЕТОНОВ В ПРИСУТСТВИИ ЩЕЛОЧИ
}

\author{
Н.А. Аксенов', Д.А. Аксенов', И.А. Куренков ${ }^{1}$, А.В. Аксенов', \\ А.А. Скоморохов', Л.А. Притыко', М.А. Рубин ${ }^{1,2}$ \\ ${ }^{1}$ Химико-Фармацевтический факультет, Северо-Кавказский федеральный университет, \\ 355017, Россия, г. Ставрополь, ул. Пушкина, д. 1. \\ ${ }^{2}$ Department of Chemistry, University of Kansas, KS 66045-7582, \\ USA, 1567 Irving Hill Rd, Lawrence
}

DOI: 10.19163/MedChemRussia2021-2021-345

E-mail: kurenkman@icloud.com

В последние годы возобновился интерес исследователей к 3,5-замещенным 5-гидрокси-1,5-дигидро-2Н-пиррол-2-онам, являющимся изомерами гетероциклического ядра тетрамовой кислоты. Соединения, включающие данную структурную единицу, встречаются в природе и демонстрируют широкий спектр биоактивности. Типичные подходы к получению таких соединений включают реакцию пятичленных предшественников лактонов с аммиаком или аминами, восстановительную циклизацию нитроолефинов с 1,3-дикетонами и т. д. Лишь несколько подходов дали хорошие результаты, однако их реализация сопряжена с использованием экзотических и дорогостоящих реактивов.

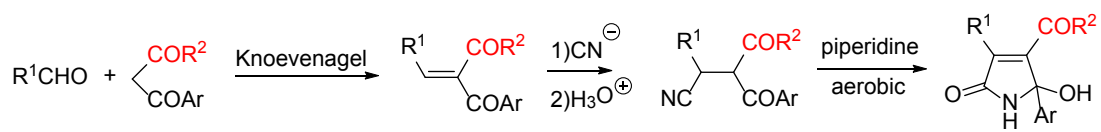<smiles>[R]C([N+]#N)C(C=[Co])C(=O)OCc1ccccc1</smiles><smiles>[R]N=C1OC([Y19])C([R])=C1[R]</smiles>

В связи с этим, мы представляем новый подход к синтезу 3,5-замещенных 5-гидрокси-1,5-дигидро-2Н-пиррол-2-онов путём циклизации коммерчески доступных 3-цианокетонов в присутствии щелочи.<smiles>[R]C(C#N)C(C#N)C(=O)Br</smiles><smiles>C[Sb]([O])(O)O</smiles><smiles>[R]C1=C([Tl])C(O)([Al])NC1=O</smiles>

Работа выполнена при финансовой поддержке Министерства образования и науки Российской Федерации (тема 0795-2020- 0031)

\section{Литература}

[1] N.A. Aksenov, D.A. Aksenov, I.A. Kurenkov, A.V. Aksenov, A.A. Skomorokhov, L.A. Prityko, M. Rubin, RSC Adv., 2021, 11, 16236. 